\title{
Antioxidant and Anti-hypercholesterolemic potential of Vitis vinifera leaves
}

\author{
Sushma Devi and Randhir Singh*
}

\section{Sushma Devi and Randhir Singh*}

Department of Pharmaceutical Sciences, Maharishi Markandeshwar University, Mullana, Ambala, Haryana, INDIA

\section{Correspondence}

Prof. (Dr.) Randhir Singh, Department of Pharmaceutical Sciences, Maharishi Markandeshwar University, Mullana, Ambala, Haryana, INDIA

Tel: +91-9896029234

E-mail: randhirsingh.dahiya@gmail.com

\section{History}

- Submission Date: 27-06-2017;

- Review completed: 21-07-2017;

- Accepted Date: 17-08-2017

DOI : 10.5530/pj.2017.6.126

Article Available online http://www.phcogj.com/v9/i6

\section{Copyright}

(C) 2017 Phcog.Net. This is an openaccess article distributed under the terms of the Creative Commons Attribution 4.0

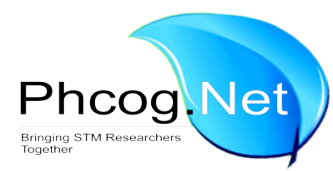

\begin{abstract}
Background: Grapes (Vitis vinifera) are universally appreciated fruit for their delicacy, nutrition and accepted as functional food. The objective of the present study is to evaluate antioxidant and anti-hypercholesterolemic potential of Vitis vinifera leaves extract. Methods: Qualitative and quantitative phytochemical screening of methanolic (VVME) and aqueous (VVAE) extract was carried out to identify the phytoconstituents. Antioxidant potential was evaluated by employing in-vitro and in vivo assays. The anti-hypercholesterolemic activity was evaluated by inducing hypercholesterolemia with high cholesterol diet for 21 days in experimental animals. Results: In WVME, total tannins, total flavonoids and total phenolic contents were found to be present in major amount. Both extract has significant in-vitro and in-vivo antioxidant efficacy. Different doses i.e. 100, 200 and $400 \mathrm{mg} / \mathrm{kg}$ of VVME and VVAE significantly attenuated the lipid levels. Moreover, VVME was found to be more effective as compared to VVAE and also, effectiveness was confirmed with histological results. Conclusion: It can be concluded that antioxidant and anti-hypercholesterolemic efficacy of Vitis vinifera might be due to presence of antioxidant property and active phytoconstituents.

Key words: Vitis vinifera, Antioxidant, Hypercholesterolemia, Cholesterol Diet, Total Phenolic Content Etc.
\end{abstract}

\section{INTRODUCTION}

Nowadays, functional food is an emerging field in food science. Functional foods are known to have positive effects on human health, such as prevention of CVD, cancer, reducing cholesterol risk and regulating the digestive system. Grape seed, fruit and their extract are already used as functional food. ${ }^{1}$ Moreover, research and commercial activities on functional food and/or ingredients are in great demand. However, there are few reports on the antioxidant activities and antidyslipidemic effects of Vitis vinifera, although it is well known that many plants have antioxidant and free radical scavenging activities.

Free radical oxidative stress, usually resulting from deficient natural anti-oxidant defenses, has been implicated in the pathogenesis of a wide variety of clinical disorders, such as the degenerative diseases, aging and the progressive decline in the immune functions. The pathological roles of free radicals have been implicated in a wide range of inflammatory diseases. ${ }^{2}$ As well as, it has been reported that hypercholesterolemia is increased free radical production and reduced free radical scavenging effect. Therefore, certain natural products with antioxidant activities may have potential anti-hypercholesterolemia actions. So, the present work was designed to evaluate the antioxidant and anti-hypercholesterolemic potential of VVME and VVAE of Vitis vinifera leaves.

\section{MATERIAL AND METHODS}

\section{Chemical used}

Cholesterol (Hi Media) cholic acid (Hi Media), Simvastatin (sample from beta drugs pvt. ltd), Aluminium chloride (Nice chemicals), Ascorbic acid (Sigma), DPPH (SD Fine), Folin ciocalteu reagent (Sigma), Gallic acid, Methanol (Nice chemicals) and spectrophotmetric analysis was carried out by using UV spectrophotometer (Shimadzu). Erba diagnostic kits were used for estimation of total cholesterol, total triglyceride and HDL levels in serum.

\section{Plant material}

Fresh leaves of Vitis vinifera was collected on April 2013 from the Tau Devilal National herbal park, Khizrabad, Haryana, India and authenticated by Dr. Shiddamallayya N., National Ayurveda Dietetics Research Institute, Banglore, India (specimen number RRCBI-MUS-125).

\section{Preparation of extract}

Leaves of Vitis vinifera was washed in water and shade dried. The dried leaves were grinded into coarse powder. Then, plant material was packed into soxhlet and extraction was carried with soxhlation for $72 \mathrm{hrs}$ using methanol aqueous. The extract was concentrated using vacuum rotary evaporator at $40^{\circ} \mathrm{C}$, dried and stored in a refrigerator at $4^{\circ} \mathrm{C}$ 
throughout the duration of study. ${ }^{3}$ The $\%$ yield of VVME and VVAE was found as $8.4 \%$ and $11.2 \% \mathrm{w} / \mathrm{w}$, respectively.

\section{Qualitative estimation of Phytoconstituents}

The qualitative phytochemical screening of VVME and VVAE was carried out to determine phytoconstituents present by using standard test. ${ }^{4-5}$

\section{Quantitative estimation of Phytoconstituents Total phenolic content ${ }^{6}$}

Total phenolic content in the extracts was determined with Folin ciocalteau reagent using gallic acid as a standard. Different concentrations $(50,100,150,250$, and $500 \mathrm{mg} / \mathrm{l})$ of gallic acid solutions were prepared. $1 \mathrm{ml}$ of solution was taken in $25 \mathrm{ml}$ volumetric flask, $10 \mathrm{ml}$ distilled water was added to each and then $1.5 \mathrm{ml}$ of the folin ciocalteu reagent was added and mixed well. After $8-10 \mathrm{~min}, 4 \mathrm{ml}$ sodium carbonate solution $(7.5 \% \mathrm{w} / \mathrm{v})$ was added and volume was adjusted upto $25 \mathrm{ml}$. Solutions was kept at $40^{\circ} \mathrm{C}$ for $30 \mathrm{~min}$ and absorbance was determined at $765 \mathrm{~nm}$ against the blank and plot absorbance vs concentration. The concentration of total phenols was expressed as $\mathrm{mg} / \mathrm{g}$ of gallic acid equivalent dry weight and experiment was performed in triplicate.

\section{Total flavonoids content ${ }^{7}$}

The aluminum chloride colorimetric method was used to determine the flavonoid content of plant extracts. $0.5 \mathrm{mg} / \mathrm{ml}$ of extract solution was added into $1.5 \mathrm{ml}$ of methanol. $0.1 \mathrm{ml}$ of $10 \%$ aluminium chloride was added followed by incubation for 5 minutes after which $0.1 \mathrm{ml}$ potassium acetate $(1 \mathrm{M})$. Finally, $2.8 \mathrm{ml}$ distill water was added and shaked and kept at room temperature for $30 \mathrm{~min}$. Absorbance of the sample was noted at $420 \mathrm{~nm}$ with UV spectrophotometer. Rutin was used as the standard for the calibration curve. From the rutin stock solution 10, 20, 30, 50 and $100 \mathrm{mg} / \mathrm{l}$ solutions was prepared. Similarly, in place of extract sample, $0.5 \mathrm{ml}$ of rutin solution was added. Flavonoid contents were expressed as $\mathrm{mg} / \mathrm{g}$ rutin equivalent dry weight. A yellow color indicated the presence of flavonoids. From the standard graph, the amount of total flavonoids content in the sample as per absorbance values was calculated and expressed as rutin equivalents $(\mathrm{mg} / \mathrm{g})$.

\section{Total tannin content ${ }^{8}$}

Total tannin content was estimated using vanillin hydrochloride method. Vanillin hydrochloride (mix equal volume of $8 \% \mathrm{HCl}$ in methanol and $4 \%$ vanillin in methanol) was freshly prepared. $1 \mathrm{ml}$ of extract solution was added in $5 \mathrm{ml}$ vanillin hydrochloride reagent and allowed to stand for $20 \mathrm{~min}$. Rutin stock containing $1 \mathrm{mg}$ rutin/ml of different concentrations $10,20,30,50$ and $100 \mathrm{mg} / \mathrm{ml}$ was prepared with methanol and absorbance was measured at $500 \mathrm{~nm}$. Total tannin content in the sample was calculated from the standard graph.

\section{Total alkaloids content ${ }^{9}$}

$1 \mathrm{mg}$ extract was dissolved in dimethyl sulphoxide (DMSO) and $1 \mathrm{ml}$ of $2 \mathrm{~N} \mathrm{HCl}$ was added and filtered. Transferred the sample into separating funnel and $5 \mathrm{ml}$ of bromocresol green solution was added and $5 \mathrm{ml}$ of phosphate buffer ( $\mathrm{pH}$ 4.7). 1, 2, 3 and $4 \mathrm{ml}$ chloroform was added by vigorous shaking, collected in volumetric flask $(10 \mathrm{ml})$ and volume was made up with chloroform. Stock solution of atropine was prepared and concentrations $20,40,60,80$ and $100 \mu \mathrm{g} / \mathrm{ml}$ was prepared in the similar manner as extract. Absorbance was measured at $470 \mathrm{~nm}$ with an UV/ Visible spectrophotometer and expressed as mg of atropine/g of extract.

\section{Total saponins content ${ }^{10}$}

$1 \mathrm{ml}$ of plant extract sample was added in methanol (80\%) and $2 \mathrm{ml}$ of vanillin in ethanol and mixed well. Then, $2 \mathrm{ml} \mathrm{H}_{2} \mathrm{SO}_{4}$ (70\%) was added and heated at temperature $60^{\circ} \mathrm{C}$ in water bath for $10 \mathrm{~min}$. Absorbance of sample was noted at $544 \mathrm{~nm}$ against blank. Diosgenin was used as standard and calibration curve was prepared. The different concentration of Diosgenin 10, 20, 40,80,150 $\mu \mathrm{g} / \mathrm{ml}$ was used for preparing standard curve. From the standard graph, the amount of saponins in the sample as per absorbance values was calculated and expressed as diosgenin equivalents $(\mathrm{mg} / \mathrm{g})$.

\section{Total steroids content ${ }^{10}$}

$1 \mathrm{ml}$ of plant extract sample was added in a $10 \mathrm{ml}$ volumetric flask and $2 \mathrm{ml} \mathrm{H}_{2} \mathrm{SO}_{4}(4 \mathrm{~N})$ and $2 \mathrm{ml}$ ferric chloride $(0.5 \% \mathrm{~W} / \mathrm{V})$ was added into the extract. Then, $0.5 \mathrm{ml}$ potassium hexacyanoferrate (III) solution $(0.5 \%)$ was added. The mixture was heated in the water bath at temperature $70 \pm 20^{\circ} \mathrm{C}$ for $30 \mathrm{~min}$. The volume was made up with distill water and absorbance was noted at $780 \mathrm{~nm}$ against blank. Cycloartenol was used as standard and different concentration of cycloartenol (10, 20, 40, 80, 160 $\mu \mathrm{g} / \mathrm{ml}$ ) was used for absorbance and standard curve. From the standard graph, the amount of steroid in the sample as per absorbance values was calculated and expressed as cycloartenol equivalents $(\mathrm{mg} / \mathrm{g})$.

\section{Total terpenoids content ${ }^{11}$}

Take $100 \mathrm{~g}$ of plant powdered material was soaked in alcohol for 20-25 h. Then, filtered and extracted with petroleum ether. Extract was evaporated, weighted and ether extract treated as total terpenoids content.

\section{Antioxidant activity (in vitro) DPPH radical scavenging activity ${ }^{12}$}

The hydrogen-donating ability of each extract was examined according to the method previously described in the presence of a DPPH stable radical. Ascorbic acid at various concentrations $(10-200 \mu \mathrm{g} / \mathrm{ml})$ was used as standard. The antioxidant activity was calculated as $\%$ inhibition using formula:

$\%$ inhibition $=\left(\mathrm{A}_{\text {blank }}-\mathrm{A}_{\text {sample }}\right) / \mathrm{A}_{\text {blank }} * 100$

$\mathrm{A}_{\text {blank }}=$ absorbance of the control

$\mathrm{A}_{\text {sample }}=$ absorbance in the presence of the extract.

\section{Superoxide radical scavenging activity ${ }^{13}$}

NBT (Nitro blue tetrazolium reagent) was used to generate the superoxide radical by auto oxidation of hydroxylamine hydrochloride and reduced into nitrite. Different concentrations $(20-500 \mu \mathrm{g} / \mathrm{ml})$ of sample were prepared and $1 \mathrm{ml}$ of $50 \mathrm{mM}$ sodium carbonate, $0.4 \mathrm{ml}$ of $24 \mathrm{mM}$ NBT $0.2 \mathrm{ml}$ of $0.1 \mathrm{mM}$ EDTA solution was added. The absorbance was recorded at $560 \mathrm{~nm}$ in $0 \mathrm{~min}$. The reaction starts after adding $0.4 \mathrm{ml}$ of $1 \mathrm{mM}$ hydroxylamine hydrochloride in the above solution and incubated at $25^{\circ} \mathrm{C}$ for 15 minute.

\section{Hydroxyl radical scavenging activity ${ }^{14}$}

Hydroxyl radical generation by phenylhydrazine was measured by 2-deoxyribose degradation assay. $1 \mathrm{mM}$ deoxyribose, was added in $50 \mathrm{mM}$ phosphte buffer ( $\mathrm{pH}$ 7.4) containing $0.2 \mathrm{mM}$ phenylhydrazine hydrochloride in a test tube. Incubation was terminated after 1 hour. $1 \mathrm{ml}$ of TCA $(2.8 \%)$ and thiobarbituric acid $(1 \% \mathrm{w} / \mathrm{v})$ was added in reaction mixture and mixture was heated for 10-15 min on water bath, cooled and the absorbance was measured at $532 \mathrm{~nm}$.

\section{Nitric oxide scavenging activity ${ }^{15}$}

For estimation of nitric oxide scavenging activity of extracts, nitrite detection method was used. Sodium nitroprusside $(10 \mathrm{~mm})$ in $0.5 \mathrm{~m}$ phosphate buffer ( $\mathrm{pH} 7.4$ ) used as source of $\mathrm{NO}$ in an aqueous solution. Further, the sample was incubated for $60 \mathrm{~min}$ at $37^{\circ} \mathrm{C}$ and Griess reagent 
(a-napthyl-ethylenediamine $0.1 \%$ in water and sulphanilic acid $1 \%$ in $\left.\mathrm{H}_{3} \mathrm{PO}_{4} 5 \%\right)$ was added. For the control reagent, same reaction mixture prepared without the extract but equivalent amount of distilled water.

\section{Antioxidant activity index ${ }^{16}$}

Antioxidant activity index (AAI) was determined by the 2,2-diphenyl1-picrylhydrazyl method proposed by Scherer and Godoy. Antioxidant activity index (AAI) was calculated by the formula:

$\mathrm{AAI}=$ final concentration of DPPH in control $/ \mathrm{IC}_{50}$

According to the AAI scale:

AAI $<0.5$ poor antioxidant activity

$0.5<\mathrm{AAI}<1.0$ moderate antioxidant activity

$1.0<\mathrm{AAI}<2.0$ strong antioxidant activity

$\mathrm{AAI}>2.0$ very strong antioxidant activity

\section{Animals}

Wistar rats (both sex) were used in the study and experimental protocol was duly approved by Institutional Animal Ethics Committee (MMCP/ IAEC/13/36). Animals were kept as per the guidelines of committee for the purpose of control and supervision of experiments on animals (CPCSEA) in Department of Pharmaceutical Sciences, Maharishi Markandeshwar University, Ambala, India. Animals were fed normal chow diet and ad libitum under controlled environmental condition of temperature $\left(24-28^{\circ} \mathrm{C}\right)$, relative humidity $60-70 \%$ and natural light/dark cycle (12:12).

\section{Antioxidant activity (in vivo) ${ }^{17}$}

Both extracts were administered in experimental animals for 7 days with different doses $(100,200$ and $400 \mathrm{mg} / \mathrm{kg})$ and serum was separated with centrifugation at a speed of $3000 \mathrm{rpm}$ for $10 \mathrm{~min}$. The level of reduced glutathione and catalase was measured in serum.

\section{Estimation of reduced glutathione ${ }^{18}$}

Reduced glutathione level was estimated by Moran et al. modified method. $1 \mathrm{ml}$ of serum was added in $6 \mathrm{ml}$ phosphate buffer $0.2 \mathrm{M}$ (pH 8.0) and $1 \mathrm{ml}$ DTNB $0.6 \mathrm{mM}$. Then, mixture was incubated at room temperature for $10 \mathrm{~min}$. The absorbance was noted at $412 \mathrm{~nm}$ and standard curve was prepared by using different concentrations $(0-50 \mu \mathrm{g} / \mathrm{ml})$ of GSH. GSH concentration was calculated using the dilution factor and expressed as $\mu \mathrm{g} / \mathrm{mg}$ of protein.

\section{Estimation of catalase activity ${ }^{19}$}

The reaction mixture $(2 \mathrm{ml})$ was containing $1.95 \mathrm{ml} \mathrm{H}_{2} \mathrm{O}_{2}(10 \mathrm{mM})$ in $50 \mathrm{mM}$ phosphate buffer ( $\mathrm{pH}$ 7.0). $0.05 \mathrm{ml}$ supernatant was added and reaction started. The absorbance was noted at $240 \mathrm{~nm}$ and phosphate buffer $(50 \mathrm{mM}, \mathrm{pH}$ 7.0) was used as standard. The extinction coefficient of $0.04 \mathrm{mM}^{-} 1 \mathrm{~cm}^{-1}$ was used and data was expressed as $\mathrm{U} / \mathrm{mg}$ protein. The unit of catalase is defined as the quantity, which decomposes $1.0 \mu$ mole of $\mathrm{H}_{2} \mathrm{O}_{2}$ per min at $\mathrm{pH} 7.0$ at $25^{\circ} \mathrm{C}$, while this $\mathrm{H}_{2} \mathrm{O}_{2}$ concentration falls from 10.3 to $9.2 \mathrm{mM}$.

\section{Induction of hypercholesterolemia with cholesterol $\operatorname{diet}^{20-21}$}

Wistar Albino rats (200-220 g) were procured under controlled environmental conditions. Atherosclerosis was induced by administration of cholesterol diet (cholesterol 2\% w/w and cholic acid $0.5 \% \mathrm{w} / \mathrm{w}$ along with basal diet) for 21 days. Simvastatin (dose $10 \mathrm{mg} / \mathrm{kg}$ ), VVME and VVAE (dose $100 \mathrm{mg} / \mathrm{kg}, 200 \mathrm{mg} / \mathrm{kg}$ and $400 \mathrm{mg} / \mathrm{kg}$ ) were administered for 21 days.

\section{Changes in body weight}

The change in the body weights was recorded weekly and \% change in body weights was calculated using formula:

$\%$ change in weight $=($ final weight- initial weight $) /$ initial weight ${ }^{\star} 100$

\section{Biochemical estimations}

At the end of study, blood was collected via retro-orbital plexus and centrifuged at $3000 \mathrm{rpm}$ for $10 \mathrm{~min}$ and serum was separated. The serum glucose, triglycerides, total cholesterol and HDL level was measured using enzymatic kits. The levels of LDL and VLDL were calculated using Friedewald equation.

\section{Liver functions test 22}

The levels of SGOT and SGPT were also analysed in the blood samples at the end of study using diagnostic kits.

\section{Histopathological studies}

Then, animals were sacrificed and heart was isolated for histopathology. A portion of heart tissue was dissected out and fixed in $10 \%$ formalin solution and histopathological studies were carried out.

\section{Atherogenic Index ${ }^{23}$}

Atherogenic index and \% protection was also calculated at the end of study using formulas:

$$
\begin{gathered}
\text { artherogenic index }=\log \left(\frac{\text { total triglyceride }}{\text { total HDL cholesterol }}\right) \\
\text { atherogenic index of control - } \\
\text { Protection }(\%)=\frac{\text { atherogenic index of treated }}{\text { atherogenic index of control }} \times 100
\end{gathered}
$$

\section{Statistical analysis}

All the data were shown mean values and represented as mean \pm SEM. Statistical analysis was done with Dunnett's multiple comparison tests using Graph pad Instat Demo software (version 3.10). In statistical analysis, $\mathrm{p}<0.05$ was considered to be significant; $\mathrm{b}=v$ s cholesterol control; $\mathrm{c}=v s 100 \mathrm{mg} / \mathrm{kg}$ dose; $\mathrm{d}=$ ss $200 \mathrm{mg} / \mathrm{kg}$ dose; $\mathrm{p}<0.05=^{*} ; \mathrm{p}<0.01=\wedge$; $\mathrm{p}<0.001=\#$.

\section{RESULTS}

\section{Qualitative and Quantitative estimation of phytoconstituents}

VVME and VVAE revealed that flavonoids, phenolic, tannins, saponins, steroids and terpenoids were present. Moreover, alkaloids were present in VVAE only (Table 1). In VVME, total tannins content, total flavonoids content and total phenolic content was found to be present in major amount (Table 2).

\section{In vitro antioxidant activity of VVME and VVAE}

In DPPH scavenging assay, $500 \mu \mathrm{g} / \mathrm{ml}$ of VVME and VVAE produced $68.25 \%$ and $62.08 \%$ inhibition. Whereas, in hydroxyl radical scavenging activity, $500 \mu \mathrm{g} / \mathrm{ml}$ of VVME and VVAE produced $54.06 \%$ and $52.75 \%$ inhibition, respectively. In superoxide radical scavenging assay ascorbic acid, VVME and VVAE produced $76.15 \%, 60.50 \%$ and $54.92 \%$ inhibition, respectively. In nitric oxide radical assay, ascorbic acid, VVME and VVAE have $86.20 \%, 65.07 \%$ and $56.09 \%$ inhibition, respectively. Antioxidant effect of VVME in different assay is in following order: 
DPPH $>$ Nitric oxide $>$ Superoxide $>$ Hydroxyl radicals. VVME was found to have strong antioxidant effect than VVAE. The antioxidant effect was found in following order: ascorbic acid > VVME > VVAE.

DPPH generate free radical and widely used to determine the antioxidant potential of various drugs and plant extracts. The inhibition mechanism of lipid oxidation is one of the known free radical scavenging activity that occurs exogenously in human body. ${ }^{24,25}$ Although superoxide anion is a weak oxidant and has important role in the generation of other ROS, like hydroxyl radical, hydrogen peroxide, or singlet oxygen which contribute to oxidative stress in living systems. ${ }^{26}$ The present study suggested that there is a strong correlation between superoxide and hydroxyl radical scavenging activity and phenolics $(22.27 \pm 1.69)$, flavonoid $(34.10 \pm 0.26)$ and tannins (33.27 \pm 0.32$)$ contents of VVME. Nitric oxide (NO) scavengers from the extracts compete with oxygen, leading to reduced production of nitrite ions. There is no significant correlation was found between NO radicals scavenging activity and phenolics. Hence, bioactive substances other than phenolics, tannins and flavonoids may be the reason for scavenging activity in extracts.

$\mathrm{IC}_{50}$ values of ascorbic acid, VVME and VVAE is shown in table $3 . \mathrm{IC}_{50}$ is used to express the concentration or amount of samples/extracts desired to scavenge $50 \%$ of the free radicals. The scavenging activity of a sample/ extract is inversely proportional to the $\mathrm{IC}_{50}$ value.

Antioxidant Activity Index (AAI) of ascorbic acid, VVME and VVAE was found to be $4.43>2.05>1.48$ respectively. According to AAI, both ascorbic acid and VVME lies into very strong category and VVAE lies into strong antioxidant category. ${ }^{16}$

\section{In vivo antioxidant activity}

Administration of different doses of VVME and VVAE significantly elevated the serum catalase level and serum reduced glutathione level. The increase in the amount of serum catalase was found to be dose dependent. In VVME $400 \mathrm{mg} / \mathrm{kg}$, the level of reduced glutathione and catalase was found maximum $(6.32 \pm 1.12 \mu \mathrm{g} / \mathrm{mg}$ of protein and $7.55 \pm 2.66 \mu \mathrm{M} / \mathrm{min} / \mathrm{mg}$ of protein) as compared to other groups (Table 4). As a preliminary step towards unveiling the mechanism of actions of these extracts in oxidative stress, their effects on common oxidative stress marker enzymes such as serum glutathione and catalase was estimated. The significant increase in serum GSH suggested that the activation of the GSH synthetic pathway does not occur as outcome of an increased production of free radicals and with non-significant depletion of the total protein. ${ }^{2}$ Also, it could be indirect pathway that one or more constituents of extract probably have some biochemical action on GSH production or affect the reduction process of GSSG to GSH. In addition, molecular evidence also suggest that the ability of some phenolic compounds to activate c-glutamylcysteine synthetase (a rate-limiting enzyme in GSH synthesis). ${ }^{27}$ According to a study, due to plant bioactive secondary metabolites, the increment in GSH concentration contributes to the chemoprevention against environmental carcinogens. ${ }^{28}$ Glutathione is vital intracellular free radicals scavenging agent and co-substrate for various enzymes. Also, it has an important role in the degradation of $\mathrm{H}_{2} \mathrm{O}_{2}$ and molecule itself undergoes oxidation process from its reduced state GSH to its oxidized state GSSG. It is active against free radicals, peroxides and other toxic compounds and protects the cells. GSH majorly involve into metabolism, catalysis and transportation. In kidney, GSH involve in the reabsorption of amino acids during transportation..$^{29}$ The enzymatic antioxidant systems such as catalase, glutathione reductase, play a coordinated role in the prevention of oxidative damage by ROS. On the other hand, catalases have heme proteins and protect the cells from toxic effects of ROS. They convert $\mathrm{H}_{2} \mathrm{O}_{2}$ into water and molecular oxygen. During aerobic metabolism, superoxide anion is being produced as a byproduct. Superoxide dismutase breaks it up into $\mathrm{H}_{2} \mathrm{O}$ and $\mathrm{H}_{2} \mathrm{O}_{2}$ and then $\mathrm{H}_{2} \mathrm{O}_{2}$ is converted to $\mathrm{H}_{2} \mathrm{O}$ and $\mathrm{O}_{2}$ by catalase..$^{30}$ Administration of extracts enhanced the antioxidant enzymes (GSH and catalase) activity in a dose dependent manner. The improved antioxidant enzymes activity may offer an effective defense system and prevent from the damage of free radicals ${ }^{2}$

Finally it can be concluded that secondary metabolites act as small molecular weight antioxidants and perform directly as antiradical agent or break chain reaction of free radical and interact with transition metals. Plants secondary metabolites can act indirectly include inhibition of ROS-generating enzymes such as xanthine oxidase or induce nitric oxide synthase or up-regulate the SOD or other enzymes activity. ${ }^{31}$ Phenolic compounds have the capability to adsorb or neutralize or quench ROS. Also, flavonoids or related compounds exhibit in vitro and in vivo antioxidant potential. ${ }^{32}$

\section{Change in body weight of experimental animals}

Hyperlipidemia or hypercholesterolemia in rats can be induced by supplementing cholesterol diet (sub-acute model). ${ }^{33}$ Excessive cholesterol feeding leads to susceptibility to hypercholesterolemia and arteriosclerosis and further promotes the development of obesity and dyslipidemia in both humans and rodents by altering the plasma cholesterol and triglyceride levels. ${ }^{34}$ According to literature, hypercholesterolemia animals are used to study the cholesterol homeostasis as convenient models. As well as, to understand the association between cholesterol metabolism disorders, a therogenesis or possible treatments to reduce lipid levels in drug trials. ${ }^{35}$ Also, administration of cholesterol diet significantly changes in the body weight of rats during the experimentation. The body weights of animals were measured weekly during 21 days of treatment. The $\%$ change in body weight of VVME $100 \mathrm{mg} / \mathrm{kg}, 200 \mathrm{mg} / \mathrm{kg}$ and $400 \mathrm{mg} / \mathrm{kg}$ group animals were found to be $14.6 \%, 12.9 \%$ and $13.2 \%$, respectively. The \% change in body weight of VVAE $100 \mathrm{mg} / \mathrm{kg}$, $200 \mathrm{mg} / \mathrm{kg}$ and $400 \mathrm{mg} / \mathrm{kg}$ groups were found to be $23.8 \%, 23.7 \%$ and $19.8 \%$ respectively.

\section{Effect of VVME and VVAE on glucose level}

$200 \mathrm{mg} / \mathrm{kg}$ and $400 \mathrm{mg} / \mathrm{kg}$ of VVME statistically lowered the glucose level as compared to cholesterol control. (Figure 1)

\section{Effect of VVME and VVAE on lipids level}

The total cholesterol level was found to be significantly elevated in experimental animals and different doses of VVME and VVAE produced a significant attenuation in serum cholesterol level. The maximum attenuation in total cholesterol level was found in VVAE $200 \mathrm{mg} / \mathrm{kg}$ $(140.2 \mathrm{mg} / \mathrm{dl})$. The total triglyceride level was elevated in the experimental animals and administration of different doses of VVME and VVAE significantly attenuated the triglyceride level. The maximum attenuation in triglyceride level was found in VVME $400 \mathrm{mg} / \mathrm{kg}$ group $(115.5 \mathrm{mg} / \mathrm{dl})$. Similarly, LDL level was also found to be significantly elevated in experimental animals and different doses of VVME and VVAE produced a significant attenuation in LDL level. The VLDL level was found to be significantly attenuated in cholesterol control as compared to normal control. Whereas, HDL level was found to be decreased in experimental animals and administration of different doses of VVME and VVAE significantly elevated the HDL level after 21 days treatment. (Figure 2-6) High cholesterol diets acts as extrinsic inducer and significantly increase the cholesterol, triglyceride, LDL levels and decrease HDL level. Increase in LDL has been indicated one of the risk factors in development of atherosclerosis and other related cardiovascular disorders. ${ }^{36} \mathrm{High}$ triglyceride levels also a marker and important risk factor that influences lipid deposition and clotting mechanisms. Numerous experimental 


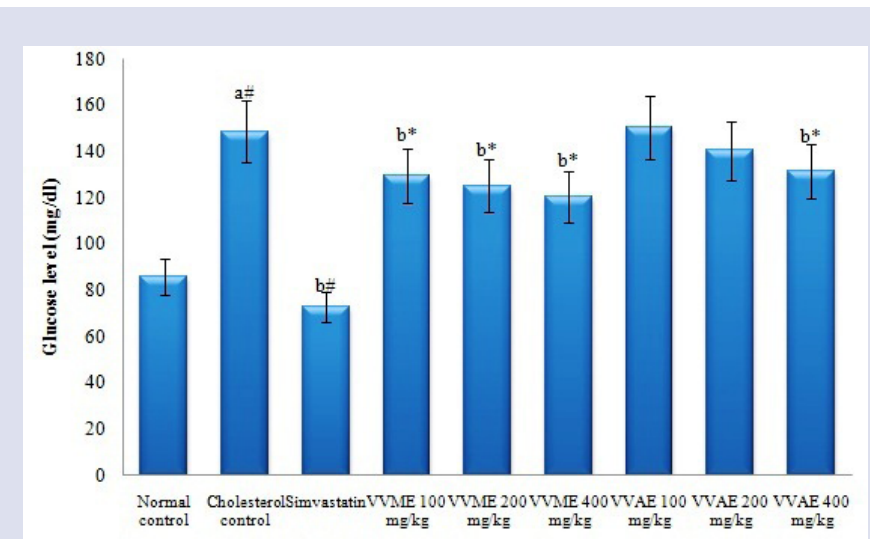

Figure 1: Effect of VVME and VVAE on glucose level in cholesterol induced hypercholesterolemia. Values are represented as mean \pm SEM, $\mathrm{n}=6$. In statistical analysis, $\mathrm{p}<0.05$ was considered to be significant; $\mathrm{a}=\mathrm{vs}$ normal control; $\mathrm{b}=$ vs cholesterol control; $\mathrm{p}<0.05={ }^{*} ; \mathrm{p}<0.01=\wedge$; $p<0.001=\#$

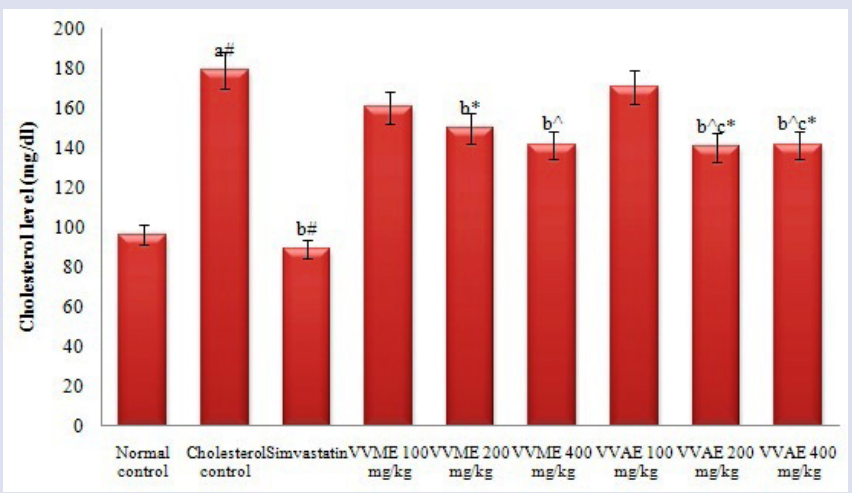

Figure 2: Effect of VVME and VVAE on cholesterol level in cholesterol induced hypercholesterolemia. Values are represented as mean \pm SEM, $\mathrm{n}=6$. In statistical analysis, $\mathrm{p}<0.05$ was considered to be significant; $a=$ vs normal control; $b=$ vs cholesterol control; $p<0.05={ }^{*} ; p<0.01=\wedge$; $p<0.001=\#$.

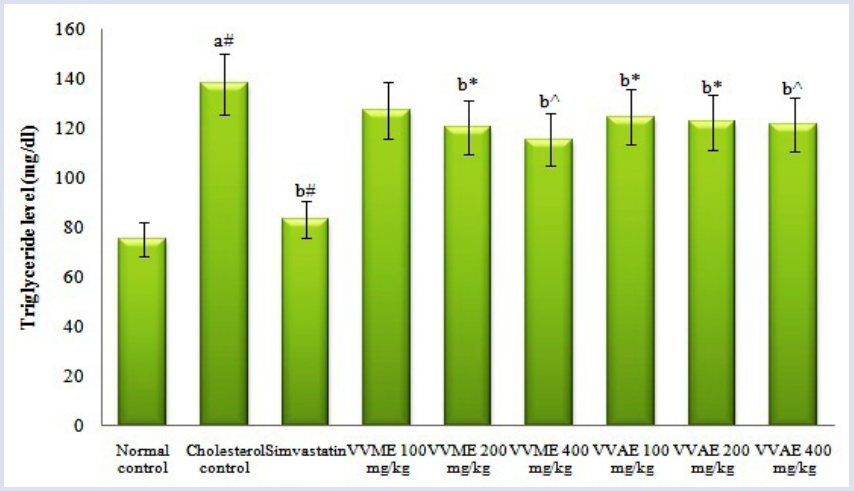

Figure 3: Effect of VVME and VVAE on triglyceride level in cholesterol induced hypercholesterolemia. Values are represented as mean \pm SEM, $\mathrm{n}=6$. In statistical analysis, $\mathrm{p}<0.05$ was considered to be significant; $\mathrm{a}=\mathrm{vs}$ normal control; $\mathrm{b}=$ vs cholesterol control; $\mathrm{p}<0.05=* ; \mathrm{p}<0.01=\wedge$; $\mathrm{p}<0.001=\#$

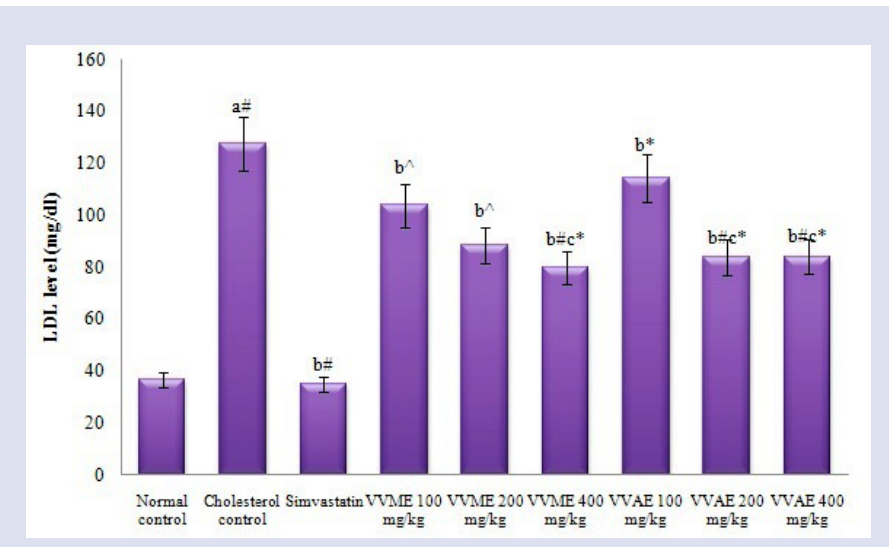

Figure 4: Effect of VVME and VVAE on LDL level in cholesterol induced hypercholesterolemia. Values are represented as mean $\pm S E M, n=6$. In statistical analysis, $p<0.05$ was considered to be significant; $a=v s$ normal control; $b=$ vs cholesterol control; $c=$ vs $100 \mathrm{mg} / \mathrm{kg}$ dose; $p<0.05=*$; $\mathrm{p}<0.01=\wedge ; \mathrm{p}<0.001=\#$.

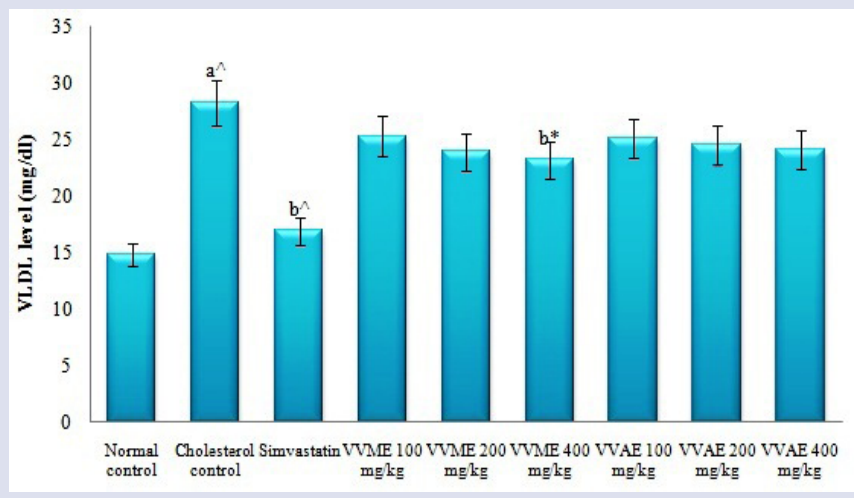

Figure 5: Effect of VVME and VVAE on VLDL level in cholesterol induced hypercholesterolemia. Values are represented as mean \pm SEM, $n=6$. In statistical analysis, $p<0.05$ was considered to be significant; $a=v s$ normal control; $b=$ vs cholesterol control; $p<0.05={ }^{*} ; p<0.01=\wedge$; $\mathrm{p}<0.001=\#$.

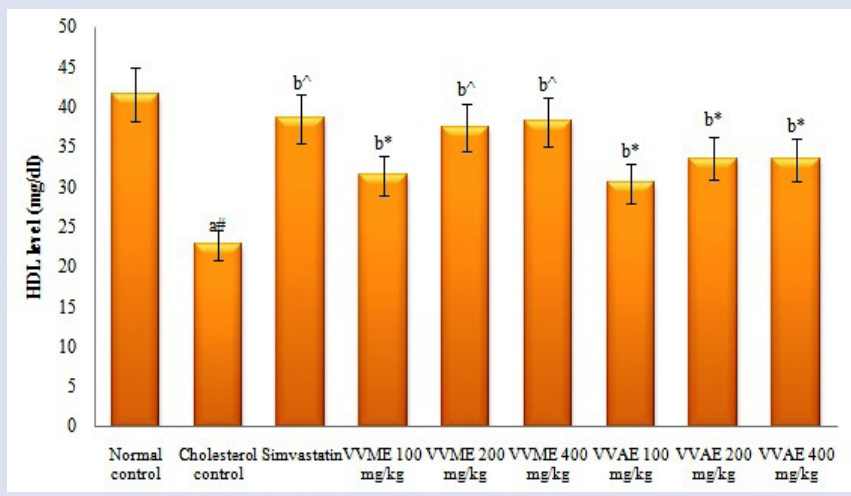

Figure 6: Effect of VVME and VVAE on HDL level in cholesterol induced hypercholesterolemia. Values are represented as mean $\pm S E M, n=6$. In statistical analysis, $p<0.05$ was considered to be significant; $a=v s$ normal control; $\mathrm{b}=$ vs cholesterol control; $\mathrm{p}<0.05={ }^{*} ; \mathrm{p}<0.01=\wedge$; $p<0.001=\#$. 


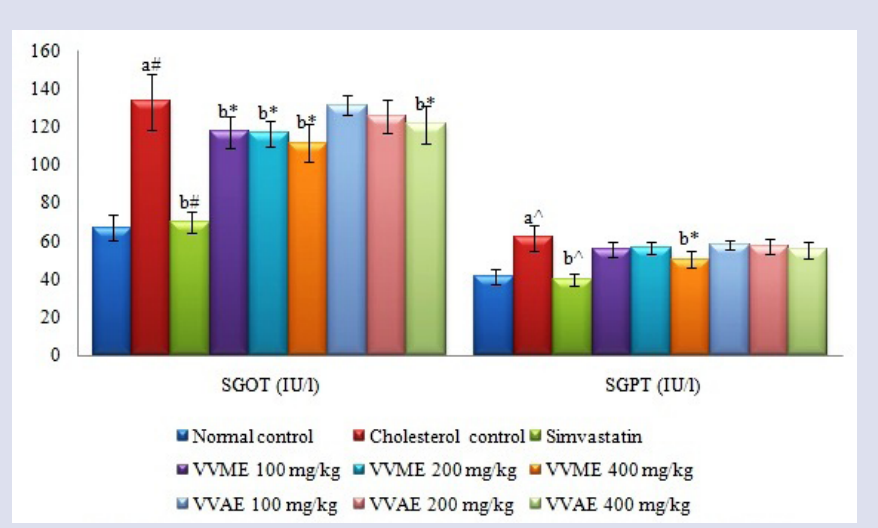

Figure 7: Effect of VVME and VVAE on SGOT and SGPT level in cholesterol induced hypercholesterolemia. Values are represented as mean \pm SEM, $\mathrm{n}=6$. In statistical analysis, $\mathrm{p}<0.05$ was considered to be significant; $a=$ vs normal control; $b=$ vs cholesterol control; $p<0.05={ }^{*} ; p<0.01=\wedge$; $p<0.001=\#$.

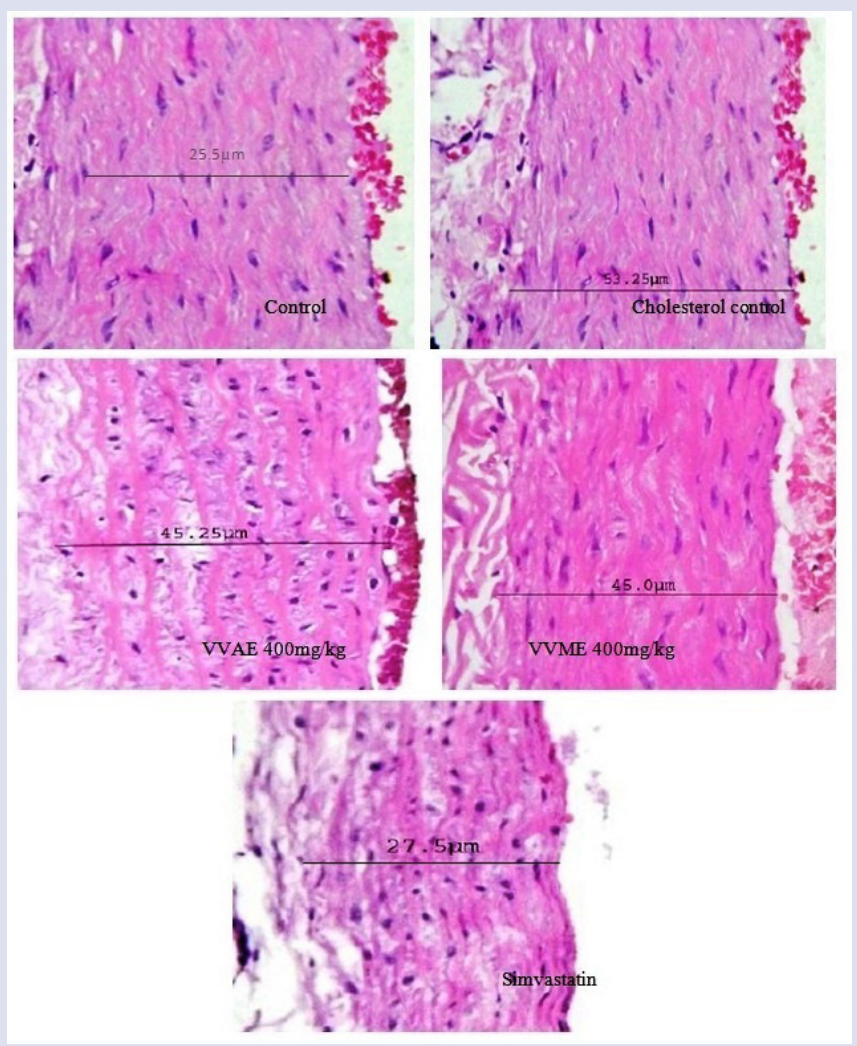

Figure 8: Histology of blood vessels (Tunica intima + media thickness) of different groups.

reports showed that cholesterol and high dietary fat induce hypercholesterolemia in animal models. ${ }^{37,38}$ Similar results were also observed with the high cholesterol diet animals have increase lipid status and increased lipid level act as indicator of establishment of hypercholesterolemia in animal models.

HDL cholesterol is inversely connected with total cholesterol and several evidences are available regarding this fact. A reduction in HDL level may impair the clearance of cholesterol from the arterial wall and speed up the development of atherosclerosis that further lead to ischemic heart diseases. ${ }^{39}$

\section{Effect of VVME and VVAE on SGOT and SGPT level}

Administration of cholesterol diet resulted in elevation of SGOT and SGPT levels in cholesterol control animals as compared to normal control after 21 days. Administration of different doses of VVME and VVAE significantly attenuated the elevated SGOT and SGPT levels. (Figure 7) The elevated level in cholesterol control animals may be due to leakage of the enzymes into the serum and damage the integrity of the heart and liver. Also, increased level of these enzymes is reported as indicators of deliberate risk of cardiovascular disease.$^{40}$ In case of severe hepatocellular injury, SGOT and SGPT are released into serum. In the absence of viral hepatitis and alcoholism, increased SGPT level can lead to a higher risk of cardiovascular disease with more risk in women. Also a high SGOT content is found in heart which becomes more elevated in myocardial infarction case. ${ }^{41}$ As well as, in the present study, histology results showed the disruption of endothelial lining in aorta, presence of foamy macrophage, increase thickness of lining and cardiovascular distress in cholesterol fed rats.

\section{Histopathology of blood vessels}

The histology of blood vessels (Tunica intima + media thickness) in cholesterol induced atherosclerosis is shown in8. In normal control section, the layers of artery and endothelial lining appeared intact and tunica intima, media and adventitia appeared within normal limits. The thickness of tunica intima + media was found to be $25.5 \mu \mathrm{m}$. In cholesterol control section, the layers of artery appeared intact except for disruption of the endothelial lining. Within the tunica intima and media were seen lipids containing elongated smooth muscle cells in single and aggregates of foamy macrophages. The tunica intima + media thickness was found to be $53.2 \mu \mathrm{m}$. In Atorvastatin section, the layers of artery and endothelial lining appeared intact. The tunica intima, media and adventitia appeared within normal limits. The thickness of tunica intima + media was found to be $27.5 \mu \mathrm{m}$. In VVME $400 \mathrm{mg} / \mathrm{kg}$ section, the layers of artery appeared intact and few areas appeared disrupted. There were seen few scattered lipid containing spindle cells between the tunica intima and tunica media. Tunica adventitia appeared within normal limits and thickness was found to be $45.0 \mu \mathrm{m}$. In VVAE $400 \mathrm{mg} / \mathrm{kg}$ section, layers of artery appeared intact except for disruption of the endothelial lining. Within tunica intima and media were seen lipids containing smooth muscle cells in single and aggregates of foamy macrophages. The thickness of tunica intima + media was found to be $45.25 \mu \mathrm{m}$.

\section{Effect on atherogenic index and \% protection}

The cholesterol control showed significant atherogenic index as compared to normal control (0.422 - high risk). In VVME $400 \mathrm{mg} / \mathrm{kg}$ found lowest atherogenic index $(0.120)$ and maximum $\%$ protection as compared to other experimental groups. (Table 5) In $400 \mathrm{mg} / \mathrm{kg}$ of VVME group, atherogenic index and lipid profile were significantly improved with an improvement in the thickening of aortic walls. It can be state that decreased lipid levels might be an experimental tool to determine anti-atherogenicity of plant extract or other metabolites. As well as, histological assessment can be considered primarily to determine the degree of degeneration of atherosclerosis in biochemical markers. ${ }^{42}$

\section{CONCLUSION}

Grapes are utilised and grape skins and seeds produced in large quantities by the winemaking industry are increasingly used to obtain functional food ingredients. ${ }^{1}$ Grapes are the better source of antioxidative constituents than skins of grape/wine byproducts. Functional ingredients of grape include several flavonoids with a phenolic nature such as monomeric flavanols, dimeric, trimeric and polymeric procyanidins, 
and phenolic acids. ${ }^{43,44}$ A few reports also indicated that extract of Vitis vinifera have strong antioxidant activity. ${ }^{45}$ According to literature, flavonoids possess many pharmacological activities like antihyperlipidemic, hypoglycemic and antidiabetic activities. The presence of tannins and saponins in medicinal plant causes the inhibition of lipid absorption. So, it may be concluded that antioxidant and anti-hypercholesterolemic efficacy of Vitis vinifera might be due to presence of antioxidant property and active phytoconstituents.

\section{ACKNOWLEDGEMENT}

Authors convey their gratitude to Beta Drugs Pvt. Ltd. and Maharishi Markandeshwar University for support of this project.

\section{CONFLICT OF INTEREST}

Authors have no conflict of interest

\section{ABBREVIATION USED}

AAI: Antioxidant activity index; CVD: Cardiovascular disease; DPPH: 2,2-diphenyl-1-picrylhydrazyl; DTNB: 5,5'-Dithiobis, 2-nitrobenzoic acid; EDTA: Ethylenediaminetetraacetic acid; GSH: Glutathione; GSSG : Glutathione disulfide; HDL: High density lipoproteins; LDL: Low density lipoproteins; NBT: Nitro blue tetrazolium; NO: Nitric oxide; ROS: Reactive oxygen species; SGOT: Serum glutamic oxaloacetic transaminase; SGPT: Serum glutamic pyruvic transaminase; SOD: Superoxide Dismutase; TCA: Trichloroacetic acid; VLDLL: Very low density lipoproteins; VVAE: Vitis vinifera aqueous extract; VVME: Vitis vinifera methanolic extract.

\section{REFERENCES}

1. Zhou T, Zhang T, Liu W, Zhao G. Physicochemical characteristics and functional properties of grape (Vitis vinifera L.) seeds protein. International journal of food science \& technology. 2011;46(3):635-41. https://doi.org/10.1111/j.13652621.2010.02532.x.

2. Rahman K. Studies on free radicals, antioxidants, and co-factors. Clinical interventions in aging. 2007;2(2):219. PMid:18044138 PMCid:PMC2684512.

3. Handa SS, Khanuja SP, Longo G, Rakesh DD. Extraction Technologies for Medicinal and Aromatic Plants, no. 66. Italy: United Nations Industrial Development Organization and the International Centre for Science and High Technology. Trieste. 2008.

4. Khandelwal KR. Practical Pharmacognosy, twelfth ed. Nirali Prakashan, Pune 2004 .

5. World Health Organization. WHO guidelines for assessing quality of herbal medicines with reference to contaminants and residues.

6. Bali EB, Açık L, Elçi P, Sarper M, Avcu F, et al. In vitro anti-oxidant, cytotoxic and pro-apoptotic effects of Achillea teretifolia Willd extracts on human prostate cancer cell lines. Pharmacognosy magazine. 2015 Oct;11(Suppl 2):S308. https:// doi.org/10.4103/0973-1296.166060; PMid:26664020 PMCid:PMC4653342.

7. Stankovic MS. Total phenolic content, flavonoid concentration and antioxidant activity of Marrubium peregrinum L. extracts. Kragujevac J Sci. 2011;33(2011):63-72.

8. Padma R, Parvathy NG, Renjith V, Kalpana PR, Rahate P. Quantitative estimation of tannins, phenols, and antioxidant activity of methanolic extract of Imperata cylindrica. Int J Res Pharm Sci. 2013;4(1):73-7.

9. Rahmalia A, Esyanti RR, Iriawati. A Qualitative and quantitative evaluation of terpenoid and alkaloid in root and stem of pasak bumi (Eurycoma longifolia Jack). J Matematika Dan Sains. 2011; 16: 49-52.

10. Patra A, Jha S, Sahu AN. Antidiabetic activity of aqueous extract of Eucalyptus citriodora hook. in alloxan induced. Pharmacogn Mag. 2009;5(19); 51-54.

11. Odoh UE, Ndubuokwu RI, Inya-Agha SI, Osadebe PO, Uzor Philip FEM. Antidiabetic activity and phytochemical screening of Acalypha wilkesiana (Euphorbiaceae) Mull arg. roots in alloxan induced diabetic rats. Scientific Res Essays. 2014;9:204-12. https://doi.org/10.5897/SRE2014.5824.

12. Shukla S, Mehta A, John J, Singh S, Mehta P, et al. Antioxidant activity and total phenolic content of ethanolic extract of Caesalpinia bonducella seeds. Food and Chemical Toxicology. 2009;47(8):1848-51. https://doi.org/10.1016/j. fct.2009.04.040; PMid:19422871.

13. Hinneburg I, Dorman HD, Hiltunen R. Antioxidant activities of extracts from selected culinary herbs and spices. Food chemistry. 2006;97(1):122-9. https:// doi.org/10.1016/j.foodchem.2005.03.028.
14. Rao BK, Kesavulu MM, Giri R, Rao CA. Antidiabetic and hypolipidemic effects of Momordicacymbalaria Hook. fruit powder in alloxan-diabetic rats. Journal of ethnopharmacology. 1999;67(1):103-9. https://doi.org/10.1016/S0378-8741(99) 00004-5.

15. Batiston WP, Swami AM, Sandra TMG, Jesuí VV, Nilson ED, Makoto M. Total phenolic content and antioxidant capacity of methanolic extracts of ten fruits. Acta Scientiarum. 2013; 35: 581-5.

16. Raut NA, Gaikwad NJ. Antidiabetic activity of hydro-ethanolic extract of Cyperus rotundus in alloxan induced diabetes in rats. Fitoterapia. 2006;77(7):585-8. https://doi.org/10.1016/j.fitote.2006.09.006; PMid:17056202.

17. Lukacínová A, Mojžiš J, Benacka R, Keller J, Maguth T, et al. Preventive effects of flavonoids on alloxan-induced diabetes mellitus in rats. Acta Veterinaria Brno. 2008;77(2):175-82. https://doi.org/10.2754/avb200877020175.

18. Okonkwo TJ, Okonkwo CJ. Antioxidant properties of Diospyros preussi (Ebenaceae Gurke) seed oil. Tropical Journal of Pharmaceutical Research. 2009;8(6).

19. Ahmad N, Mukhtar H. Green tea polyphenols and cancer: biologic mechanisms and practical implications. Nutrition reviews. 1999;57(3):78-83. https://doi. org/10.1111/j.1753-4887.1999.tb06927.x; PMid:10101921.

20. Machhi JP, Shah NN. Study of antiatherosclerotic activity of polyherbal preparation using rat as an experimental animal model. International Journal of Pharmaceutical Sciences and Research. 2012;3(10):4010.

21. Parasuraman $S$, Balamurugan $S$, Christapher $P V$, Petchi RR, Yeng WY, et al. Evaluation of Antidiabetic and Antihyperlipidemic Effects of Hydroalcoholic Extract of Leaves of Ocimum tenuiflorum (Lamiaceae) and Prediction of Biological Activity of its Phytoconstituents. Pharmacognosy research. 2015;7(2):156. https://doi.org/10.4103/0974-8490.151457; PMid:25829789 PMCid:PMC4357966.

22. Shao F, Gu L, Chen H, Liu R, Huang H, Ren G. Comparation of hypolipidemic and antioxidant effects of aqueous and ethanol extracts of Cratae. Pharmacogn Mag. 2016; 12(45): 64-69. https://doi.org/10.4103/0973-1296.176049; PMid:27019563 PMCid:PMC4787339

23. Millán J, Pintó X, Mu-oz A, Zú-iga M, Rubiés-Prat J, Pallardo LF. Lipoprotein ratios: Physiological significance and clinical usefulness in cardiovascular prevention. Vasc Health Risk Manag. 2009; 5: 757-65. PMid:19774217 PMCid:PMC2747394.

24. Cotelle N, Bernier JL, Catteau JP, Pommery J, Wallet JC, Gaydou EM. Antioxidant properties of hydroxy-flavones. Free Radical Biology and Medicine. 1996;20(1):35-43. https://doi.org/10.1016/0891-5849(95)02014-4.

25. Barros L, Ferreira MJ, Queiros B, Ferreira IC, Baptista P. Total phenols, ascorbic acid, $\beta$-carotene and lycopene in Portuguese wild edible mushrooms and their antioxidant activities. Food chemistry. 2007;103(2):413-9. https://doi. org/10.1016/j.foodchem.2006.07.038.

26. Rahal A, Kumar A, Singh V, Yadav B, Tiwari R, et al . Oxidative stress, prooxidants, and antioxidants: the interplay. BioMed research international. 2014 https://doi.org/10.1155/2014/761264; PMid:24587990 PMCid:PMC3920909.

27. Olukanni OD, Akande OT, Alagbe YO, Adeyemi OS, Olukanni AT, et al. Lemon juice elevated level of reduced glutathione and improved lipid profile in Wistar rats. American-Eurasian Journal of Agricultural \& Environmental Sciences. 2013;13(9):1246-51.

28. Abraham SK, Singh SP. Anti-genotoxicity and glutathione S-transferase activity in mice pretreated with caffeinated and decaffeinated coffee. Food and chemical toxicology. 1999;37(7):733-9. https://doi.org/10.1016/S0278-6915(99)00053-8.

29. Alam MN, Bristi NJ, Rafiquzzaman M. Review on in vivo and in vitro methods evaluation of antioxidant activity. Saudi Pharmaceutical Journal. 2013; 21(2):143-52. https://doi.org/10.1016/j.jsps.2012.05.002; PMid:24936134 PMCid:PMC4052538.

30. Sharma P, Jha AB, Dubey RS, Pessarakli M. Reactive oxygen species, oxidative damage, and antioxidative defense mechanism in plants under stressful conditions. Journal of Botany. 2012. https://doi.org/10.1155/2012/217037.

31. Malomo SO, Ore A, Yakubu MT. In vitro and in vivo antioxidant activities of the aqueous extract of Celosia argentea leaves. Indian journal of pharmacology. 2011;43(3):278. https://doi.org/10.4103/0253-7613.81519; PMid:21713091 PMCid:PMC3113379

32. Cartea ME, Francisco M, Soengas P, Velasco P. Phenolic compounds in Brassica vegetables. Molecules. 2010;16(1):251-80. https://doi.org/10.3390/ molecules16010251; PMid:21193847.

33. Vogel HG. Drug Discovery and Evaluations. Pharmacological assays. VogelWH, Schölkens BA, Sandow J, Müller G and Vogel WF. Springer-Verlag Berlin Heidelberg New York, 2nd edition 2002. https://doi.org/10.1007/3-540-29837-1.

34. Klop B, Elte JW, Cabezas MC. Dyslipidemia in obesity: mechanisms and potential targets. Nutrients. 2013;5(4):1218-40. https://doi.org/10.3390/nu5041218; PMid:23584084 PMCid:PMC3705344

35. Otunola GA, Oloyede OB, Oladiji AT, Afolayan AA Effects of diet-induced hypercholesterolemia on the lipid profile and some enzyme activities in female Wistar rats. African Journal of Biochemistry Research. 2010;4(6):149-54.

36. Bitzur R, Cohen $H$, Kamari $Y$, Shaish A, Harats D. Triglycerides and HDL cholesterol. Diabetes care. 2009 Nov 1;32(suppl 2):S373-7. https://doi. org/10.2337/dc09-S343; PMid:19875584 PMCid:PMC2811435

37. Cherng JY, Shih MF. Preventing dyslipidemia by Chlorella pyrenoidosa in rats and 
hamsters after chronic high fat diet treatment. Life sciences. 2005;76(26):3001-13. https://doi.org/10.1016/j.Ifs.2004.10.055; PMid:15850594.

38. Shao F, Gu L, Chen H, Liu R, Huang H, et al. Comparation of hypolipidemic and antioxidant effects of aqueous and ethanol extracts of Crataegus pinnatifida fruit in high-fat emulsion-induced hyperlipidemia rats. Pharmacognosy magazine. 2016;12(45):64. https://doi.org/10.4103/0973-1296.176049; PMid:27019563 PMCid:PMC4787339.

39. Vergeer M, Holleboom AG, Kastelein JJ, Kuivenhoven JA. The HDL hypothesis: does high-density lipoprotein protect from atherosclerosis?. Journal of lipid research. 2010;51(8):2058-73. https://doi.org/10.1194/JIr.R001610; PMid:20371550 PMCid:PMC2903818.

40. Botros M, Sikaris KA. The de ritis ratio: the test of time. Clin Biochem Rev. 2013;34(3):117-30. PMid:24353357 PMCid:PMC3866949.

41. Kim W, Flamm SL, Di Bisceglie AM, Bodenheimer HC. Serum activity of alanine aminotransferase (ALT) as an indicator of health and disease. Hepatology. 2008;47(4):1363-70. https://doi.org/10.1002/hep.22109; PMid:

\section{GRAPHICAL ABSTRACT}

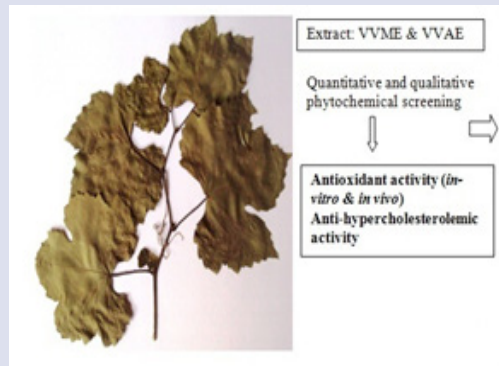

\section{AUTHOR PROFILE}

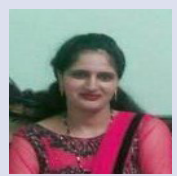

Sushma Devi: Sushma Devi, Ph.D. Scholar (Pharmacology) in Maharishi Markandeshwar University, Mullana, Haryana, India.

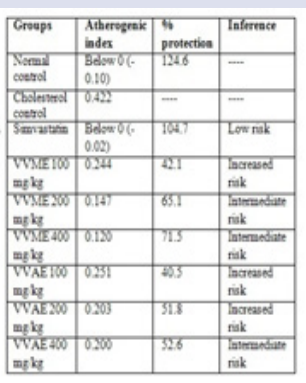

\section{HIGHLIGHTS OF PAPER}

- In methanolic extract, total tannins, total flavonoids and total phenolic contents were found in major amount.

- Different doses of extracts significantly attenuated the lipid levels and effectiveness was confirmed with histological results.

- VVME was found to be more effective as compared to WAE.

- Antioxidant and anti-hypercholesterolemic efficacy of Vitis vinifera might be due to presence of antioxidant property and active phytoconstituents.

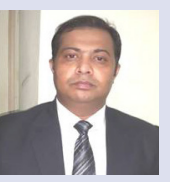

Randhir Singh: Dr. Randhir Singh, prof. (Pharmacology) in Maharishi Markandeshwar University, Mullana, Haryana, India. Presently working on a project of DST under the Young Scientist Award.

Cite this article : Devi S and Singh R. Antioxidant and Anti-hypercholesterolemic potential of Vitis vinifera leaves. Pharmacog J. 2017;9(6):807-814. 